Developing an occupational perspective of women involved in sex work - a discussion paper

Rachel Rule ${ }^{\mathrm{a}}$ \& Rebecca Twinley

${ }^{a}$ Occupational Therapist - Community Mental Health Team, Plymouth, UK.

ORCID: https://orcid.org/0000-0003-3005-2891 Twitter: @_rachelOT

'Lecturer in Occupational Therapy, University of Brighton, UK. ORCID: https://orcid.org/0000-0003-2128-0921 Twitter: @RebeccaTwinley

Disc

losure statement: The authors have no financial interests to disclose. 


\title{
Developing an occupational perspective of women involved in sex work - a discussion paper
}

\begin{abstract}
Sex work is a commonplace form of work that is variably tolerated, or not, worldwide. Perceived by many to be a complex social issue, sex work is interpreted and performed differently, depending on the political, religious, cultural, and legal context - all of which shape the dominant cultural narrative regarding stigmatising perceptions of sex workers. The aim of our discussion paper is to outline reflections and to offer some arguments on the challenges and opportunities of addressing sex work from an occupational perspective. We focus on three issues: the push and pull factors of sex work, a critical consideration of the common assumption that health can be promoted through occupation, and the contribution that occupational science can provide for sex workers.
\end{abstract}

Keywords: community, the dark side of occupation, sex work, stigma, push and pull factors

\section{Introduction}

Sex workers should not have to defend the sex industry to argue that we deserve the ability to earn a living without punishment. People should not have to demonstrate that their work has intrinsic value to society to deserve safety at work. Moving towards a better society - one in which more people's work does have wider value, one in which resources are shared on the basis of need - cannot come about through criminalisation. Nor can it come about through treating marginalised people's material needs and survival strategies as trivial (Smith and Mac, 2018, p. 55).

It is well-established that patterns of occupation vary depending on the socioeconomic and political contexts in which they occur (Moll, Gewurtz, Krupa, \& Law, 2013). The value of occupation in promoting health and wellbeing is recognised by occupational scientists and therapists (Townsend \& Polatajko, 2013; Wilcock, 1998, 2006), who acknowledge the significance of the interdependent interactions between people, the environment, occupation, and how this affects choice and participation (Christiansen, Baum, \& Bass, 2014; Taylor \& Kielhofner, 2017; Law, Cooper, Strong, Stewart, Rigby, \& Lets, 1996). Consequently, 
considering society through an occupation focused lens could encourage collaborative working with communities who are deemed to be a 'social problem' (Parnell \& Wilding, 2010; Lauckner, Leclair, \& Yamamoto, 2019). Women who engage in sex work are such a community, who are often socially stigmatised, marginalised and alienated.

In this discussion, we use the term 'occupational perspective' as a way to consider the subjective experience of occupations as experienced by people, as individuals, and within their daily context, including as members of [said] society within which they live. The focus of the discussion is predominantly upon the United Kingdom (UK) context, as the authors acknowledge there are many diverse and contextual factors to consider when exploring sex work. It is important, let alone timely, that occupational science addresses sex work because it is a profession with a long-standing history, and sex workers themselves are a vulnerable community who have experienced long-enduring social marginalisation and stigma. There is an argument that sex workers are themselves community workers, with varying experiences and reasons for either wanting to stay in or to leave sex work; hence our discussion reflects on the push and pull factors of sex work. As such, this discussion contributes to illuminating an aspect of the dark side of occupation, which is: "a concept developed in response to growing awareness that there are aspects of people's subjective experience of occupation that have yet to be explored from an occupational perspective" (Twinley, 2017, p. 30). The second section therefore provides a critical consideration of the common assumption that health can be promoted through occupation. In terms of sex work, it is deemed necessary to 1) challenge theory that implies work is intrinsically beneficial to health and 2) to explore the occupation of sex work, as well as those occupations related to sex work, whereby a positive contribution to health and wellbeing can be questioned. The paper ends with an exploration of the contribution that occupational science can provide for sex workers.

\section{Perceptions of sex work}

Sex work is said to hold a provocative place in the social psyche (McCray, Wesely, \& Rasche, 2011). Sex workers are a community that have received little recent address in occupation focused research or policy, yet, in the UK the House of Commons (2016) estimate that 72,800 people work as sex workers; within the report itself there is recognition of the difficulties with making an estimate for this community. Brooks-Gordon, Mai, Perry \& Sanders (2015) report that $88 \%$ of sex workers are women, which includes both transgender 
and cisgender women, though, it is recognised that men and gender-diverse individuals also engage in sex work. Sex work can be something a person chooses and consents to do, or something a person has been forced or coerced into doing by a third party. Our discussion focuses on adult women, not girls (or children), as the tendency to merge women and girls' experiences suggests women have shared experiences with girl youths in sex work (Stella, 2013).

The degree to which sex work is inherently exploitative is a key issue in contemporary discourse. Many allies and sex workers themselves would suggest there are those who voluntarily work as sex workers and who are not exploited: 'There is a continuum of positions from those who argue that the sex industry is by definition exploitative, through to those who argue that most women exercise considerable choice and agency, and are thus not exploited' (Kelly, 2003). Where people voluntarily engage, sex work refers to direct and indirect sexual encounters and interactions between two or more adults for some form of payment. The very use of the term 'sex worker' recognises that sex work is work - a service that can be sold in exchange for money or goods. People who sell sexual services are understood to prefer this term over prostitution, which can be demeaning and stigmatising and is suggestive of sex work as criminal and immoral (Open Society Foundations, 2019). Sex workers are a broad and diverse community, with an equally broad and diverse experience of performing sex as work. In Western societies, the modern stereotype prevails that women are victims of exploitative male clients. Further, Smith and Mac (2018) report that the relationship between sex workers and the wider feminist movement has historically been fraught. There are various feminist perspectives to consider, for instance, the abolitionist feminist argument upholds the view that sex work is akin to slavery and is inherently exploitative and violent (Heath, Braimoh, \& Gouweloos, 2016). Further, the "Nordic" or "Swedish Model" of sex work describes the approach to the criminalisation of the purchasing of sex. This is based on an ideological framework that sees all sex as violence, and is understood as part of an exclusionary feminist framework that seeks to abolish sex work (Nielson, 2018; Kingston \& Thomas, 2019). Though, there are many feminists who support the rights of sex workers to engage in their work, as Wahab (2004) describes, liberal feminists reject that sex workers are victims in need of rescuing, and proclaim that sex is a commodity and, as such, women should have agency over their bodies. Ray (2012), however, dismisses the 'happy hooker' myth as being simplistic and reactive. An alternative paradigm, 
depicted by Horn (2018), moves towards a labour centred focus to sex work, through a Marxist feminist perspective, focusing on organising control over women's lives and work.

Evidently, sex work is a complex social issue that is perceived and performed differently, depending on the socioeconomic, political, religious, cultural, and legal context within which it takes place. As discussed by Smith (2017), the contextual elements of sex work can include the type of sex work that women engage in, as well as race, social structures, gender, and age. Overwhelmingly, the dominant cultural narrative is one which stigmatises sex workers - even in those countries where sex work is legal - and acts to oppress sex workers through shaping cultural norms that justify the maintenance of myths about this community; this breeds hatred toward sex workers themselves that is deep-rooted in a historically misogynistic discourse about sex.

\section{The push and pull factors of sex work}

In contrast to prevailing stereotypes, it is recognised that sex workers come from a wide range of socio-economic contexts; to illustrate, an increase in evidence shows that university students enter sex work to help fund their studies (Sanders \& Hardy, 2015). There are indeed many faces of sex work. We, the authors, live in England (UK), where it is legal to sell and purchase sexual services between consenting adults, though most other aspects of sex work, such as soliciting, working indoors with friends or facilitating sex work are illegal (House of Commons, 2016). Smith and Mac (2018) interpret that the only way to engage in sex work legally in Britain is to work alone and indoors. This raises major safety concerns, as a global systematic review carried out by Deering et al. (2014) found that $45-75 \%$ of sex workers experienced violence at work, including rape, robbery, and assault, which for some women has been lethal (All-Party Parliamentary Group's, 2014). Further, when considering transgender women, there is the potential for an increased risk of threats, violence, and harassment if they choose to disclose their status, or are otherwise outed (National Ugly Mugs, 2019). Oselin (2010) and Drucker and Nieri (2016) report that the desire to exit sex work can emerge due to these dangerous conditions, in addition to burnout, incompatibility with religious beliefs, becoming jaded, wanting to build relationships, and to maintain sobriety. 
Undoubtedly, these factors raise serious health, wellbeing, and safety concerns, particularly in the context of human trafficking, whereby people are forced into labour, including sex work, through coercion, abduction, and/or the abuse of power (United Nations, 2000). Through exploration of the occupational injustices of human trafficking, George and Stanley (2018) recognise multiple push and pull factors, including the occupational marginalisation that pushes people from their homes, across borders and into vulnerable and dangerous situations, to the pull factor of the promise of 'a better life'. For example, in the case study of 'Maya' (US Department of State, 2017), George and Stanley (2018) describe how Maya fled her country due to conflict and was promised a good job in a factory. Maya was subsequently forced into sex work, along with seventy other women and experienced significant trauma and occupational deprivation.

Human trafficking and sex trafficking are evidently serious issues requiring targeted intervention, however, assumptions must not be made about all migrant sex workers. Mai (2009) asserts that from a qualitative study of 100 migrant sex workers less than $6 \%$ reported feeling that they were coerced; a pull factor for remaining in the sex industry for those included in this study was that sex work was preferred in comparison to the unrewarding and exploitative conditions experienced in other jobs often carried out by women. For example, the Clean Clothes Campaign (2015) estimated that $75 \%$ of people employed globally in the textiles industry are women. An industry renowned for lack of a living wage, serious health and safety concerns and restrictions to freedom (Business and Human Rights Resource Centre, 2018). What is more, a study from The English Collective of Prostitutes (2019) interviewed sixteen women including five migrant workers, three women of colour, and women living with various physical and mental health conditions. They compared sex work and a variety of traditional jobs in the UK that are typically carried out by women, such as: care and support work, nursing, hairdressing, and waitressing. They found that sex workers earned more per hour, worked fewer hours, and that sex work fitted in well with their lifestyles and responsibilities. Supporting this, a longitudinal study of 130 female sex workers in London explored their career and health patterns over a fifteen-year period, finding that many women reported that their occupation was socially functional and provided economic benefits (Ward \& Day, 2006). Mayhew and Mossman's (2007) global, scoping review of best practice interventions for women leaving sex work also recognises that sex work can have a multitude of benefits for women, including being economically advantageous, and therefore exit is not always desired. 
Sex work can offer flexibility, social connection, and can be a vehicle to social mobility, such as home ownership. Despite the stigma and risk, this can explain why many women choose to stay in the industry, especially in consideration also of the current global climate of poverty and destitution, and the associated number of people living in extreme poverty around the world. Additionally, other issues impact, such as those that are witnessed here in the UK with the use of zero-hour contracts (Gov.UK, 2019), which sees employers offering hours when they need work completed, leaving employees without any guarantee of work. Whilst the illegal aspects of sex work mean that sex workers have few rights in the workplace, neither do many of the women engaging in legal work (English Collective of Prostitutes, 2019). Further, in addition to the potential risks posed towards transgender women in sex work, significant difficulties can also arise for transgender women in the traditional workplace such as being excluded, persistent use of the wrong pronouns and other serious forms of bullying (Government Equalities Office, 2015); despite the existence of the Sex Discrimination Act (1975). Jacques (2010) recognises that given this, and the fetishization of the pre-operative male to female body, it is unsurprising that many transgender people engage in sex work. Though, the 2016 report from the House of Commons estimates that only $4 \%$ of sex workers in the United Kingdom are transgender. The other issue is, and always had been, that the problematisation of commercial sex work by policymakers detracts from the realities of sex workers, especially those identified as working class and in poverty; these are people whose realities involve daily concerns like paying for electricity or feeding their children. Roberts, who worked in the sex industry in the 1980s, illustrates how criminalising what can be the final option to survive poverty is not the solution; rather, poverty itself needs to be tackled:

Working in crummy factories for disgusting pay was the most degrading and exploitive work I ever did in my life ... I think there should be another word for the kind of work working class people do; something to differentiate from the work middle class people do; the ones who have careers. All I can think of is drudgery. It's rotten and hopeless; not even half a life. It's immoral. Yet as I say, it's expected of working class women that they deny themselves everything ... Why should I have to put up with a middle class feminist asking why I didn't do anything - scrub toilets even? Than become a stripper? What's so liberating about cleaning up other people's shit? (1986, p. 232-3). 
Sage (2019) who is a writer, activist and sex worker, describes sex work as a customer service job where workers are paid to create a fantasy. Sage goes on to describe a want to enter the sex industry to explore a sex workers' own sexual interests as potentially misguided, as whilst workers often develop deep and intimate bonds with clients, these interactions are not symmetrical with the client needs and experiences. In contrast, Smith (2017) explored nine female sex workers' experiences of intimacy and pleasure in their work. A participant in this study described struggling to achieve sexual pleasure in relationships prior to engaging in sex work. Another participant spoke of Eastern spirituality providing an alternative way to think about women's sexuality through sex work, enabling her to encompass both the client's enjoyment and her own. This demonstrates that, like other jobs, sex work does not always have a uniform effect on women's psyche and self-image (Weitzer, 2009).

Overall, gender inequalities within societal structures should be considered in their responsibility for sex work becoming the only option for some women (Sanders, O'Neill, \& Pitcher, 2009). It must be recognised that many of the factors that draw women into sex work remain as factors that cause difficulty in exiting, causing regular re-entry (McCray, Wesely, \& Rasche, 2011; Oselin, 2010). Regardless of reasons to enter the industry, involvement exposes women to high amounts of risk, yet, provision of support to leave falls predominantly to independent charities in the UK (House of Commons, 2016). What is more, the focus of research with sex workers leaves a multitude of health and occupational needs unaddressed. For instance, current globally prioritised health promotion for sex workers focuses pre-dominantly on the prevention of sexually transmitted and other diseases, these include: condom programming, human immunodeficiency virus testing and counselling, prevention and management of hepatitis and tuberculosis, and reproductive health interventions (World Health Organisation, 2019). Yet, when considering the shared life experiences of these women, NIA (2019), a charity working with sex workers in the UK, reports that many women live with complex vulnerabilities, including: histories of abuse and violence, experiences of trauma and coercion, mental and physical illness, substance misuse, and criminal records. These factors can cause difficulties with health management, identity, building new relationships, and transitions to alternate vocational roles (Wilson \& Butler, 2013).

Although almost a third of the 240 sex workers included in a survey by Sanders, Connelly, and King (2016) hold university degrees, many women engage in sex work to escape poverty 
(English Collective of Prostitutes, 2019). Therefore, if women choose to leave sex work, they face reducing their socioeconomic status due to financial instability, limited occupational skills, limited alternative employment options, and homelessness (Drucker \& Nieri, 2016; Murphy, 2010; Oselin, 2010; Preble, 2015; Sanders, O’Neill, \& Pitcher, 2009). Supporting this, a transnational review of women leaving sex work found that economic opportunities are a critical strategy to prevent return to the industry (Wilson, Critelli, \& Rittner, 2015). Given that a systematic review by Lago et al. (2018) found that low socioeconomic status is associated with worse health outcomes, this must be an area of consideration.

\section{Promoting health through occupation: challenging common assumptions}

Considering the push and pull factors of sex work exposes the need to challenge the common assumption that health can be promoted through occupation, and to consider occupation in all its complexity; indeed "Exploring the range of occupations a person subjectively experiences might enhance our understanding of how some can lead people to experience good health but poor states of wellbeing, and vice versa" (Twinley, 2016, 89-90). It is certainly appreciated that people's experiences and environments have the potential to facilitate, or constrain, engagement in occupation (Brown, 2009). Exploration of community, socioeconomic, and political issues using an occupational lens may reveal solutions hidden by narrower disciplinary focuses (Moll et al., 2013), thus informing advocates for equity, justice, and the inclusion of sex workers in community life (Ecklund, Arana, Henning, Lopez, Patel \& Varnell, 2018; Taylor \& Kielhofner, 2017; Townsend \& Polatajko, 2013). Amongst the limited literature available that explores sex workers experiences from an occupational perspective, Ecklund et al's (2018) phenomenological study describes the facilitators and barriers to occupational participation for six female exotic dancers leaving the industry; the complexity of the findings highlights a need for further research into the occupational lives of sex workers and how occupational deprivation can impact women after leaving sex work.

Overall, allied health professionals have been urged to become better equipped in their knowledge of social diversity (Needle, Petchy, Benson, Scriven, Lawrenson, \& Hilari, 2011). The stigma sex workers face contributes to their marginalisation, especially from health, social, and legal services (Open Society Foundations, 2019). Conceivably, this is a more complex concern for women who are trafficked migrants and/or for those who do not speak the language of the country they have been trafficked to. It is known that such women, who 
are trafficked migrants and who work in the sex industry are very vulnerable to health risks because of their dependence on the trafficker (Kofman, Lukes, D'Angelo \& Montagna, 2009). Additionally, for women from different minority ethnic and cultural backgrounds, it must be considered how health and wellbeing services in the UK may be received, considering the diversity of people's first-hand accounts and impressions of living, especially in terms of migration history, culture, language, religions and health profiles.

From an occupational perspective, the contribution to health promotion and prevention is based upon the assumption that health and well-being is supported by engagement in meaningful occupation (Ikiugu, Hoyme, Mueller \& Reinke, 2015). However, contrarily to this, there are many occupations, including many of those related to sex work, which may "challenge the pervasive belief in a causal relationship between occupation and health" (Twinley, 2017, p. 29). Sex workers are far from a homogeneous group (Mayhew \& Mossman, 2007) and occupation focused research pursuits must be appropriately targeted. Logically, with the ability to gain access and consent, there is scope to work with women to explore their experiences as individuals whilst they are part of their practice or circumstance community (of sex workers), within the wider community (place) in which they all live and work.

\section{The contribution that occupational science can provide for sex workers}

Sex work is an area of human occupation that is rarely included in occupational science discourse, likely because this has been preoccupied with the essential aspects of occupation that are linked with well-being, such as engagement and meaning (Watters, 2013). Research illuminating the lived experiences of sex workers is needed, as this can produce an insight into their occupational experiences, focusing on key or priority occupational needs.

Considered from a practical occupational science perspective, there could be exploration of the impact (including any benefits or any impediments) of the occupation of sex work in daily life. Learning from researchers who have conducted projects with sex workers, research should be approached in a participant (or respondent) centred way in order to build in the respect for human dignity (Shaver, 2005). This is very much in line with approaches used by occupational scientist researchers, regardless of whether their research is at the individual, group, or population level. Additionally, any occupational science endeavours must attend to working ethically with a stigmatised population (where sex workers are visible) or hidden 
populations (where sex workers work inside) engaged in stigmatised occupations (Shaver, 2005).

So long as stigma prevails, so will occupational apartheid, which is the systematic segregation of populations, denying access to quality occupations, education or work, based on prejudice (Hocking, 2017; Wilcock \& Hocking, 2015). Goffman's (1990) seminal work on stigma recognises that people become stigmatised because of socially 'undesirable' qualities resulting in their identity becoming 'spoiled', which can have a permeating effect on health and wellbeing. We urge that remaining occupationally conscious - that is, respecting and upholding the power and complexity of human occupation - is key to disrupting the cycle of oppression experienced by people who are socially excluded, living in poverty, and limited by political and cultural powers (Kronenberg, Pollard, \& Ramugondo, 2011; Ramungondo, 2015).

For those women seeking to leave sex work, and when attempting to apply for alternative vocations, having gaps in work history or needing to explain their previous vocation could leave women feeling vulnerable and excluded. The stigma of working in the sex industry can continue for a long time, preventing women from accessing other meaningful working roles that could meet their needs and promote their autonomy, health, and wellbeing (Sallman, 2010; Wilcock \& Hocking, 2015). Further, in the transition of leaving sex work, there is a process of identity transformation to move through. For instance, the sex workers in Oselin's (2009, pp. 380) study recounted beliefs about their identity, of "being a prostitute" and "wanting to do and be something different". A person's identities are not static, they change over time and across many contexts (Becker, 1963; Goffman, 1959), and they are shaped by each individual's subjective experience of occupation.

For those women who stay in sex work, the issue of belonging in relation to the occupational identity as a sex worker is complex. Conceivably, the very occupation of sex work could be understood as contributing to the well-being of other people, either through features such as reducing stress (Wong, Holroyd, \& Bingham, 2011), contributing to their local economy (Pitcher, Campbell, Hubbard, O’Neill \& Scouler, 2006), or even directly contributing financially to supporting their community, such as Badi women in Nepal (Deb, 2006). We propose there is a need for the current theory regarding belonging, occupation, and well- 
being to develop in response to such considerations. However, there are conflicting issues that must be considered in any effort to explore occupation, belonging, and the community context within which sex work occurs. For instance, in the UK, the main guidance and legislation relating to sex work is of a criminal, rather than protective or empowering nature; accordingly, the National Police Chief's Council (2019) reports on the impact that visible sex workers can have on communities, with residents complaining of fear of lower house prices and restricted business opportunity, littering of discarded condoms and syringes, noise, impingement of public spaces, children witnessing sexual activity, fears for the welfare of sex workers, and increase of associated crime. These are very real concerns that are, however, not supported by any credible evidence base: "The evidence that sex work is a problematic issue is rather limited, but it is clear that sex workers themselves are not considered community members and are rarely consulted about their own concerns and needs" (Cooper \& Maginn, 2016, para 7). Occupational science can contribute to exploring ways to enhance community awareness beyond the prevailing myths of sex work.

In terms of methodological design, literature suggests it might be necessary to utilise creative ways to communicate with communities about marginalised groups, such as use of photovoice; this was developed by Carol Wang and Ann Burris in 1997 as a research method which adopts a grassroots approach to social change, aiming to reduce stigma and promote self-expression, empowerment, and engagement in change (Sutton-Brown, 2015). Photovoice aims to promote critical dialogue with stakeholders and policy makers about community topics and populations, by using ethnographic techniques. Desyllas (2014) successfully engaged in a Photovoice project with sex workers in America, capturing images of the sex workers' everyday environments and facilitating artistic self-expression as an act of resistance to societal stigma. Photovoice projects have the potential to become a local resource for education, particularly as these narratives are often not heard elsewhere (Pollard \& Parks, 2011), therefore highlighting their power in uncovering nuances from people that are seen as 'hard to reach', invisible, or silenced from those working in traditional health and social care environments (Kronenberg, Pollard, \& Ramugondo, 2011).

In the UK, contemporary government policies appear receptive to an occupational perspective, however occupational science research must be designed and conducted in partnership with, amongst others, those organisations that represent government agencies, 
service providers, and the people using services (Mounter and Illot, 2000). Occupational scientists need to be cognisant of issues taking place on a larger scale, including some of the structural interventions proposed by the World Health Organisation (2019) to support the autonomy, health, and wellbeing of women in sex work, including: supportive legislation and policy, addressing stigma, community empowerment, and addressing violence. Social divisions are forged by the combined political contexts and power dynamics of communities, which prevent community participation and fair access to resources (Jewkes \& Murcott, 1996). In their systematic review of community involvement in the development of policy, Conklin, Morris \& Notle (2015) found that to increase service-community collaboration, service users should be involved in consumer boards, co-design, and co-production. Further, the inclusion of an occupational science perspective at the policy development and planning stages of projects could assist organisations to consider the occupational and wellbeing purposes of their ventures (Parnell \& Wilding, 2010).

One of the barriers perceived as preventing health services from engaging sex workers comes from Commonweal Housing (2019), who provide accommodation for women leaving sex work in the UK. They state that mainstream organisations do not have the knowledge or awareness of sex work to feel comfortable in raising conversations about sex work. Such factors reinforce stigma, which prevents disclosure to health care providers and is detrimental to people's health seeking efforts (Dourado et al., 2019). Therefore, links must be created with organisations, preferably with input from women with lived experience, to close this gap. In general, health care should not be preoccupied solely with people who have diagnoses or disabilities but, instead, concerned with human wellbeing overall (Christiansen, 1999; Hammell, 2008) and, specifically, an occupational perspective must challenge the dominant narratives about sex work.

\section{Conclusion}

Our discussion has, we hope, led you to question the extent to which you feel prepared to adapt your theoretical, practical, and/or research approaches for working with culturally diverse people and, specifically, with people whose occupations vary enormously in their forms and social contexts, such as women engaged in or wanting to leave sex work. Unsurprisingly, the stigma associated with sex work leads to the marginalisation of sex 
workers, regardless of culture. This compounds the challenges of addressing sex work from an occupational perspective, even when contemplating those women whose lived experiences transcend the dominant narrative that sex workers are all unwilling victims and, rather, who make the liberated and conscious choice to stay in sex work.

Advancing an occupational perspective of women who stay in or want to leave sex work requires astute political awareness, which involves understanding features of the lived experience of sex workers, such as other people's or agency's hidden agendas, power relationships, citizenship, rights, stigma, inequalities, and injustice. Evidently, there are various push and pull factors of sex work. Sex workers are a diverse community, the majority are vulnerable, and none are prioritised for health promotion beyond that which relates to their sexual services. Our discussion has highlighted the scope there is to engage with women who have experience of sex work to explore and promote social and occupational equity, justice, autonomy, and inclusion in community life. An occupational perspective has the capacity to amplify the voices of sex workers by empowering them to tell their stories and to illuminate and document their everyday subjective experiences of occupation.

\section{References.}

All-Party Parliamentary Group (2014). Shifting the Burden. Retrieved from https://appgprostitution.files.wordpress.com/2014/04/shifting-the-burden.pdf

Becker, H. S. (1963). Outsiders: studies in sociology of deviance. New York: The Free Press.

Brooks-Gordon, B., Mai, N., Perry, G. \& Sanders, T. (2015). Production, Income, and Expenditure from Commercial Sexual Activity as a measure of GDP in the UK National Accounts. Report for Office of National Statistics (ONS). Retrieved from http://eprints.bbk.ac.uk/17962/1/17962.pdf 
Brown, C. (2009). Ecological models in occupational therapy. In Crepeau, E. S., Cohn, E. B. \& Boyt Schell, B. A. (1 $11^{\text {th }}$ ed.). Willard and Spackman's occupational therapy (pp. 435-445). Philadelphia: Lippincott Williams and Wilkins.

Business and Human Rights Resource Centre (2018, April). European textile industry and human rights due diligence: Key developments, human rights allegations and best practices. Retrieved from https://www.businesshumanrights.org/sites/default/files/EU_Textile_Briefing_Final.pdf

Christiansen, C. (1999). Defining lives: Occupation as identity: An essay on competence, coherence, and the creation of meaning. American Journal of Occupational Therapy, 53, 547558. DOI: 10.5014/ajot.53.6.547

Christiansen, C., Baum, C., \& Bass, J.D. (2014). Health, Occupational Performance and Occupational Therapy. In Christiansen, C., Baum, C., \& Bass, J.D ( $4^{\text {th }}$ ed.). Occupational therapy: Enabling function and well-being (pp. 16-29). Thorofare: SLACK, Inc.

Clean Clothes Campaign (2015, February). Factsheets. Retrieved from https://cleanclothes.org/resources/publications/factsheets

Conklin, A., Morris, Z. \& Nolte, E. (2015). What is the evidence base for public involvement in health-care policy: Results of a systematic scoping review. Health Expectations, 18(2), 153-165. DOI: 10.1111/hex.12038. 
Cooper, E. \& Maginn, P. (2016) How sex work can improve your neighbourhood. Retrieved from https://www.independent.co.uk/news/uk/how-sex-work-can-improve-yourneighbourhood-a7090036.html

Deb, S. (2006). Children in Agony: A source book. New Dheli: Concept Publishing Company.

Deering, K. N., Argento, E., Duff, P., Garcia-Moreno, C., Shoveller, J., Amin, A., Shannon, K., \& Nesbitt, A. (2014). A systematic review of the correlates of violence against sex workers. American Journal of Public Health, 104(5), 42-54. DOI:

10.2105/AJPH.2014.301909.

Desyllas, M. C. (2014). Using photovoice with sex workers: The power of art, agency and resistance. Qualitative Social Work, 13(4), 447-501. DOI: 10.1177/1473325013496596

Dourado, I., Guimarães, M.D.C., Damacena, G.N., Magno, L., de Souza Júnior, P.R.B., Szwarcwald, C.L. \& The Brazilian FSW Group. (2019). Sex work stigma and non-disclosure to health care providers: data from a large RDS study among FSW in Brazil. $B M C$ International Health and Human Rights. 19, 1-8. DOI: 10.1186/s12914-019-0193-7

Drucker, J., \& Nieri, T. (2016). Female online sex workers' perceptions of exit from sex work. Deviant Behavior, 39(1), 1-19. DOI: 10.1080/01639625.2016.1257890

Eckland, E., Arana, J., Henning, L., Lopez, J., Patel., R. \& Varnell, J. (2018) Exploring the 
role of occupational therapy with women leaving the sex industry. American Journal of Occupational Therapy, 72, 1. DOI: 10.5014/ajot.2018.72S1-PO4046

English Collective of Prostitutes (2019). What's a nice girl like you doing in a job like this? A comparison between sex work and other jobs commonly done by women. Retrieved from http://prostitutescollective.net/wp-content/uploads/2019/02/Nice-Girl-report.pdf

George, E. and Stanley, M. (2018) Exploring the occupational injustices of human trafficking. Journal of Occupational Science, 26(3), 394-407. DOI:

$10.1080 / 14427591.2018 .1515104$

Goffman, E. (1959). The moral career of the mental patient. In Rubington, E. \& Weinberg, M. S. (9 ${ }^{\text {th }}$ ed.). Deviance: The Interactionist Perspective (pp. 120-129). Boston: Pearson Education, Inc.

Goffman, E. (1990). Stigma. Notes on the management of a spoiled identity. New Jersey: Prentice Hall, Inc.

Gov.UK (2019). Zero-Hours Contracts. Retrieved from https://www.gov.uk/contract-typesand-employer-responsibilities/zero-hour-contracts

Government Equalities Office. (2015). The recruitment and retention of transgender staff. Guidance for employers. Retrieved from https://assets.publishing.service.gov.uk/government/uploads/system/uploads/attachment_data 
/file/484855/The_recruitment_and_retention_of_transgender_staff_guidance_for_employers.pdf

Hammell, K. W. (2008). Reflections on well-being and occupational rights. Canadian Journal of Occupational Therapy, 75, 61-64. DOI: 10.2182/cjot.07.007

Heath, M., Braimoh, J. \& Gouweloos, J. (2016). Judging women's sexual agency: Contemporary sex wars in the legal terrain of prostitution and polygamy. Signs, 42(11), 199225. DOI: $10.1086 / 686771$

Hocking, C. (2017). Occupational justice as social justice: the moral claim for inclusion. Journal of Occupational Science, 24(1), 29-42. DOI: 10.1080/14427591.2017.1294016

Horn, M. (2018). Why do Marxist feminists oppose liberal feminists' claims that porn and prostitution are liberating for women? Retrieved from https://morningstaronline.co.uk/article/why-do-marxist-feminists-oppose-liberal-feministsclaims-porn-and-prostitution-are

House of Commons (2016). Prostitution. Retrieved from https://publications.parliament.uk/pa/cm201617/cmselect/cmhaff/26/26.pdf Jacques, J. (2010). No wonder many transsexual people end up in sex work. Retrieved from https://www.theguardian.com/lifeandstyle/2010/aug/25/transsexual-people-sex-work 
Jewkes, R. \& Murcott, A. (1996). Meanings of community. Social Science and Medicine, 43, 555-563. DOI: 10.1016/0277-9536(95)00439-4

Kelly, L. (2003). The Wrong Debate: Reflections on Why Force is Not the Key Issue with Respect to Trafficking in Women for Sexual Exploitation. Feminist Review: Exile and Asylum - Women Seeking Refuge in 'Fortress Europe', 73, 139-144. DOI:

10.1057/palgrave.fr.9400086

Kingston, S. \& Thomas, T. (2019) No model in practice: a 'Nordic model' to respond to prostitution? Crime Law and Social Change, 71(4), 423-439. DOI: 10.1007/s10611-018$9795-6$

Kofman, E., Lukes, S., D’Angelo, A. \& Montagna, N. (2009). The equality implications of being a migrant in Britain. Middlesex: Social Policy Research Centre, Middlesex University. Retrieved from https://www.equalityhumanrights.com/sites/default/files/research-report-19the-equality-implications-of-being-a-migrant-in-britain.pdf

Kronenberg, F. Pollard, N. \& Ramugondo, E. (2011). Introduction: Courage to dance politics. In Kronenberg, F. Pollard, N. \& Sakellariou, D. (2 ${ }^{\text {nd }}$ ed.). Occupational Therapy without borders: Towards an ecology of occupation-based practices (pp. 1-16). Edinburgh: Elsevier.

Lago, S., Cantarero, D., Rivera, B., Pascual, M., Blazquez-Fernandez, C., Casal, B., \& Reyes, F. (2018). Socioeconomic status, health inequalities and non-communicable diseases: a systematic review. Journal of Health Sciences, 26(1), 1-14. DOI: 10.1007/s10389-017-0850Z 
Lauckner, H., Leclair, L. \& Yamamoto, C. (2019). Moving beyond the individual: Occupational therapists' multi-layered work with communities. British Journal of Occupational Therapy, 82(2), 101-111. DOI: 10.1177/0308022618797249

Law, M., Cooper, B., Strong, S., Stewart, D., Rigby, P., \& Letts, L. (1996). The personenvironment-occupation model: A transactive approach to occupational performance. Canadian Journal of Occupational Therapy, 63, 9-23. DOI: $10.1177 / 000841749606300103$

Mai, N. (2009). Migrant Workers in the UK Sex Industry: Final Policy-Relevant Report. Swindon: Economic and Social Research Council.

Mayhew, P., \& Mossman, E. (2007). Exiting prostitution: models of best practice. New Zealand: Ministry of Justice.

McCray, K., Wesely, J. K., \& Rasche, C. E. (2011). Rehab retrospect: Former prostitutes and the (re)construction of deviance. Deviant Behavior, 32(8), 743-768. DOI: $10.1080 / 01639625.2010 .514224$

Moll, S. E., Gewurtz, R. E., Krupa, T., \& Law, M. C. (2013). Promoting an occupational perspective in public health. Canadian Journal of Occupational Therapy, 80, 111-119. DOI: $10.1177 / 0008417413482271$ 
Mounter, C.R. and Ilott, I. (2000). Occupational science: Updating the United Kingdom journey of discovery. Occupational Therapy International, 7(2), 111-120. DOI:

10.1002/oti.111

Murphy, L. S. (2010). Understanding the Social and Economic Contexts Surrounding Women Engaged in Street Level Prostitution. Issues in Mental Health Nursing, 31(12), 775784. DOI: $10.3109 / 01612840.2010 .524345$

National Police Chief's Council. (2019). National Policing Sex Work and Prostitution Guidance. Retrieved from http://library.college.police.uk/docs/appref/Sex-Work-andProstitution-Guidance-Jan-2019.pdf

National Ugly Mugs. (2019) Trans sex workers. Retrieved from https://uglymugs.org/um/safety/transgender-sex-workers/

Needle, J. J., Petchy, R., Benson, J., Scriven, A., Lawrenson, J. \& Hilari, K. (2011). The allied health professions and health promotion: a systematic literature review and narrative synthesis. Southampton: National Institute for Health Research.

Nielsen, A. (2018, July). Nordic Model: The Ongoing Criminalization of Sex Workers in Northern Europe. Retrieved from https://medium.com/@aleknielsen/nordic-model-theongoing-criminalization-of-sex-workers-in-northern-europe-c1df02ba94ae

NIA (2019). Prostitution. Retrieved from http://www.niaendingviolence.org.uk/prostitution/index.php 
Open Society Foundations (2019). Understanding Sex Work in an Open Society. Retrieved from https://www.opensocietyfoundations.org/explainers/understanding-sex-work-opensociety

Oselin, S. (2009). Leaving the Streets: Transformation of Prostitute Identity within the Prostitution Rehabilitation Program. Deviant Behavior, 30(4), 379-406. DOI:

$10.1080 / 01639620802258485$

Oselin, S. (2010). Weighing the consequences of a deviant career: Factors leading to an exit from prostitution. Sociological Perspectives, 53, 527-550. DOI: 10.1525/sop.2010.53.4.527

Parnell, T., \& Wilding, C. (2010). Where can an occupation-focussed philosophy take occupational therapy. Australian Occupational Therapy Journal, 57(5), 345-348. DOI: 10.1111/j.1440-1630.2010.00860.x

Pitcher, J., Campbell, R., Hubbard, P., O’Neill, M. \& Scouler, J. (2006) Living and working in areas of street sex work: From conflict to coexistence. Bristol: The Policy Press.

Pollard, N. \& Parks, S. (2011). Community publishing: occupational narratives and 'local publics. In Kronenberg, F. Pollard, N. \& Sakellariou, D. (2 ${ }^{\text {nd }}$ ed.). Occupational Therapy without borders: Towards an ecology of occupation-based practices (pp. 171-178). Edinburgh: Elsevier. 
Preble, K. M. (2015). Creating trust among the distrustful: a phenomenological examination of supportive services for former sex workers. Journal of aggression, maltreatment and trauma, 24(4), 433-453. DOI: 10.1080/10926771.2015.1022291

Ramugondo, E. L. (2015). Occupational Consciousness. Journal of Occupational Science, 22(4), 488-501. DOI: 10.1080/14427591.2015.1042516

Ray, A. (2012). Why the sex positive movement is bad for sex workers' rights. Retrieved from https://audaciaray.tumblr.com/post/20228032642/why-the-sex-positive-movement-is-bad-for$\operatorname{sex}$

Roberts, N. (1986). The front line; women in the sex industry speak. London: Grafton Books.

Sage, J. (2019, July 31). Why going into sex work isn't as easy as it sounds. Retrieved from https://www.pghcitypaper.com/pittsburgh/why-going-into-sex-work-isnt-as-easy-as-itsounds/Content?oid=15522518

Sallman, J. (2010). Living with stigma: Women's experiences of prostitution and substance use. Affilia, 25(2), 146-159. DOI: 10.1177/0886109910364362

Sanders, T., O’Neill, M. \& Pitcher, J. (2009). Prostitution: Sex work, policy and politics. Thousand Oaks, CA: Sage. 
Sanders, T., Connelly, L., \& King, L. J. (2016). On Our Own Terms: The Working Conditions of Internet-Based Sex Workers in the UK. Sociological Research Online, 21(4), 1-14. DOI: $10.5153 /$ sro. 4152

Sanders, T. \& Hardy, K. (2015). Students selling sex: marketisation, higher education and consumption. British Journal of Sociology of Education, 36, 747-765. DOI:

$10.1080 / 01425692.2013 .854596$

Sex Discrimination Act (1975) c.65 Retrieved from http://www.legislation.gov.uk/ukpga/1975/65/enacted

Shaver, F.M. (2005). Sex Work Research: Methodological and Ethical Challenges. Journal of Interpersonal Violence, 20(3), 296-319. DOI: 10.1177/0886260504274340

Smith, E. M. (2017). "It gets very intimate for me": Discursive boundaries of pleasure and performance in sex work. Sexualities, 20(3), 344-363. DOI: 10.1177/1363460716665781

Smith, M., \& Mac, J. (2018). Revolting Prostitutes: The fight for sex worker's rights. London: Verso.

Stella (2013). Language matters: Talking about sex work. Retrieved from https://www.nswp.org/sites/nswp.org/files/StellaInfoSheetLanguageMatters.pdf 
Sutton-Brown, C. A. (2015). Photovoice: a methodological guide. Photography and Culture, 7(2), 169-185. DOI: 10.2752/175145214X13999922103165

Taylor, R. R., \& Kielhofner, G. (2017). Introduction to the model of human occupation. In Taylor, R. R (5 $5^{\text {th }}$ ed.). Kielhofner's Model of Human Occupation: Theory and Application (pp. 3-11). Philadelphia: Wolters Kluwer.

Townsend, E. A., \& Polatajko, H. J. (2013). Enabling occupation II: Advancing an occupational therapy vision for health, well-being, and justice through occupation. (2 ${ }^{\text {nd }}$ ed.). Ottawa: Canadian Association of Occupational Therapists.

Twinley, R. (2013). The dark side of occupation: a concept for consideration. Australian Occupational Therapy Journal, 60(4), 301-303. DOI: 10.1111/1440-1630.12026

Twinley, R. (2016). The perceived impacts of woman-to-woman rape and sexual assault, and the subsequent experience of disclosure, reaction, and support on victim/survivors' subjective experience of occupation. (Doctoral thesis). Retrieved from PEARL, https://pearl.plymouth.ac.uk/handle/10026.1/6551

Twinley, R. (2017). The Dark Side of Occupation. In Jacobs, K. and MacRae, N. (3rd ed.). Occupational Therapy Essentials for Clinical Competence (pp: 29-36). Thorofare, NJ: 
SLACK Inc.

United Nations. (2000). Protocol to prevent, suppress and punish trafficking in persons especially women and children, supplementing the United Nations Convention against Transnational Organized Crime. Retrieved from http://www.ohchr.org/EN/ProfessionalInterest/Pages/ProtocolTraffickingInPersons.aspx

US Department of State. (2017). Trafficking in persons report 2017. Retrieved from https://www.state.gov/j/tip/rls/tiprpt/2017/

Wahab, S. (2004). Tricks of the trade: What social workers can learn about female sex workers through dialogue. Qualitative Social Work, 3(2), 139-160. DOI:

$10.1177 / 1473325004043378$

Ward, H., \& Day, S. (2006). What happens to women who sell sex? Report of a unique occupational cohort. Sexually Transmitted Infections, 85(2), 413-417. DOI:

10.1136/sti.2006.020982

Watters, A.M., Pearce, C., Backman, C.L. and Suto, M.J. (2013). Occupational Engagement and Meaning: The Experience of Ikebana Practice. Journal of Occupational Science, 20(3), 262-277, DOI: 10.1080/14427591.2012.709954

Weitzer, R. (2009). Sociology of sex work. Annual Review of Sociology, 35(1), 213-234. DOI: 10.1146/annurev-soc-070308-120025 
Wilcock, A. A. (1998). An occupational perspective of health. Thorofare: SLACK, Inc.

Wilcock, A. A. (2006). An occupational perspective of health. (2nd ed.). Thorofare: SLACK, Inc.

Wilcock, A. A., \& Hocking, C. (2015). An occupational perspective of health. (3rd ed.). Thorofare: SLACK, Inc.

Wilson, B., \& Butler, L. D. (2013). Running a gauntlet: A review of victimisation and violence in the pre-entry, post-entry and peri-/post-exit periods of commercial sexual exploitation. Psychological Trauma: Theory, research, practice and policy, 6(5), 494-504. DOI: $10.1037 / \mathrm{a} 0032977$

Wilson, B., Critelli, F. M., \& Rittner, B. A. (2015). Transnational responses to commercial sexual exploitation: A comprehensive review of interventions. Women's Studies International Forum, 48(1), 71-80. DOI: 10.1016/j.wsif.2014.10.005

Wong, W.W.W., Holroyd, E. \& Bingham, A. (2011). Stigma and sex work from the perspective of female sex workers in Hong Kong. Sociology of Health \& Illness, 33(1), 50-65. DOI: $10.1111 /$ j.1467-9566.2010.01276.x 
World Health Organisation (2019). Sex Workers. Retrieved from

https://www.who.int/hiv/topics/sex_work/about/en/ 